\title{
THE PRINCIPLE MANAGEMENT IN IMPROVING TEACHER PROFESSIONAL AT STATE ISLAMIC MODEL SENIOR HIGH SCHOOLOF BANDA ACEH AND STATE SENIOR HIGH SCHOOL ABULYATAMA OF ACEH BESAR
}

\author{
Suparta Rasyid ${ }^{\text {a* }}$

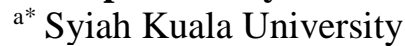 \\ Jl. Teuku Nyak Arief No.441, Kota Banda Aceh, Indonesia, suparta07rasyid@gmail.com
}

\begin{abstract}
Implementation of leadership in improving teacher professionals, and principal programs which is very important to do especially in the principal program and the purpose of education it self. The purpose of this research is to know: the formulation of the program, the implementation of management, and the obstacles faced by the principal in running the management in improving the professional teacher. This research uses descriptive method with qualitative approach. Data collection techniques: observation, interview, and documentation study. The subjects of this study were principals, vice principals, teachers, MGMP, school committees, supervisors, and outstanding teachers. The results of this study indicate that: (1) The principal's program in improving teacher professionals, the formulation mechanism begins with deliberations between stakeholders as well as principals, Chair of the MGMP, School committees, supervisors, and outstanding teachers. Prepared programs, long-term, medium and short-term programs, and all these programs are guided by the provincial government of Aceh. All of this is already in the principal's management as embodied in the principal's program to improve teacher professionalism. (2) the principal conducts the principal's management to improve the teacher's professionalism by applying subordinates and principals taking approaches to improve teacher professionalism. For teachers who excel in the form of promoting the name of the teacher to follow CAKEP, and promoted. (3) the obstacles faced by the principal in improving teacher professionals to find teachers who are still less than the maximum in the work or the teacher is less concerned about the situation at school.
\end{abstract}

Keywords: Headmaster, Management, and Teacher Professional

Received: 12 June 2018 - Revised: 15 Sep 2019 - Accepted 12 Nov 2019 - Available online 30 Dec 2019

\section{INTRODUCTION}

Indonesia's national education aims to develop the potential of learners to become human beings who believe and piety to God Almighty, morality, healthy, knowledgeable, capable, creative, independent and become citizens of democratic and responsible as stated in the law No. 20 of 2003 on the national education system in article 1 . For the purpose of the achievement of that goal established an Indonesian national education system implemented to the cultural roots and philosophy of the nation of oriented to global competition in the progress of world civilization through the management of national education.

National education management organizes every component of the education system, educators and educators, curriculum learners and infrastructure facilities, systematically in order to produce educational output in accordance with these objectives. In practice, Nana Fattah (2008: 1) revealed the operations of each of the components can not be separated from the educational system management functions: planning (planning), organizing (organizing), the leader (leading) and controlling (Controlling). These functions 
aim to regulate the process of educational activities, including in schools as a vehicle for education, in order to run well in order to achieve effectiveness and efficiency.

To improve the quality of education as expected, not only demanded the role of teachers, but the principal also plays a role in it. The principal is the leader or top manager at his school. It is the driving force of all available resources in schools, be it teacher resources, administrative staff and students. Thus on teachers, principals should be able to influence, encourages, directs teachers so that they perform their duties optimally. Thus, the expected role of the principal is the effectiveness or management of the principal in mobilizing the teachers. Buchari Zainun (2004) states that the activities or management of leaders in generating teacher work motivation as subordinates include: attention to subordinates, participation, communication in all directions, recognition, delegation and creating a competitive climate.

\section{METHODS}

The approach used in this research is qualitative approach by using descriptive. Descriptive research methods in research methods that aim to describe field conditions research at the present moment or when the study was conducted. The data collected in the analysis is qualitative to obtain the meaning of the observed phenomenon. Creswell (2012) says that; "Qualitative research is the process of exploring and understanding the meaning of individual and group behavior, describing social problems or humanitarian problems". Qualitative whole purpose is to reach an understanding of how people feel in the process of life, to give of meaning, and describes how people to implementation experience. Data collection can be done in various settings, various sources, various ways. When viewed from settings-the data can be collected in natural settings, in laboratory experimental methods, in schools with education and education personnel, at home with various respondents, at a seminar, discussion, on the street and others. Data and information that have been obtained by the next researcher, analyzed and interpreted from the beginning of the research to the end of the research by referring to the theoretical foundation relating to the problem under study. Data analysis in this qualitative research is done by classifying, directing, disposing unnecessary, and organizing data (reducing data), summarizing the principal (display data) and withdrawal of conclusion (data verification).

\section{RESULTS AND DISCUSSION}

\section{A. Principal Program}

The results show that the principal's program to improve the professional competence of teachers dissolves at the beginning of the school year by the school supervisory team which includes annual and semester programs and has not been well documented and neat. The program is planned to conduct guidance to teachers regularly in the form of guidance on the preparation of Learning Plans (RPP), implementation of learning, implementing MGMP in schools and the procurement of teaching aids or learning media

\section{B. Implementation of Principal Management}

Based on the results of this study, it can be concluded that the implementation of management/ program to improve the professional competence of teachers begins by delivering briefings at the beginning of each semester. In the implementation of school activities, the principal seeks to create safe and comfortable school habits and situations. The development of school habits is directed at measurable objectives to facilitate the achievement of professional teacher competence improvement. To support this program, principals apply reward and punishment systems.

\section{Obstacles to Implementation of Principal Management}

Based on the research results can be concluded that the obstacles faced by the principal in improving the professional 
competence of teachers is that teachers still lack the technology, there are still less teachers mastering the subject matter, and teachers are still lacking in applying the learning method in accordance with their respective materials, the number of tasks of the current school principal, and in the absence of a standard school program, and which during the different course or treatment given to teachers, especially to teachers under the auspices of KEMENAG

\section{CONCLUSION/RECOMENDATION}

a) The principal's program for improving the professional competence of teachers is prepared at the beginning of the school year by the school development team that includes the year program and the smester program, and has not been well documented and neat.

b) Implementation of the program to improve the professional competence of teachers begins by delivering briefings at the beginning of each smester.

c) Efforts are made to overcome barriers that occur with coaching and motivation, sending teachers to attend trainings, providing necessary instructional media and reviving the MGMP program..

\section{REFERENCES}

Buchari, Zainun 2004. Administration and human resource management of the Government of the Republic of Indonesia a.

Euis, Doni. 2013. Principal Management and Professionalism Building a Quality School. Bandung: Alfabeta.

Marzuwan. Principal Leadership As Manager in Improving Education Quality in SMA Negeri 1 Meureudu. Journal of Educational Administration of Unsyiah, Vol. 4, No. 3, August 2016.

Sugiyono (2017). Educational Research Methods Quantitative Approach, Qualitative, and R \& D. Bandung: Alfabeta.

Yusrizal (2016). Measurement and Evaluation of Learning Outcomes and Processes. Yogyakarta: Pale Media Prima. 